\title{
ION-EXCHANGE PROPERTIES OF THE NATURAL ZEOLITE AMICITE
}

\author{
Nikita V. Chukanov ${ }^{1,}$,, Olga N. Kazheva ${ }^{1}$, Nadezhda A. Chervonnaya ${ }^{1}$, Dmitry A. Varlamov ${ }^{2}$, \\ Vera N. Ermolaeva ${ }^{1}$, Igor V. Pekov ${ }^{3}$, Gennadiy V. Shilov ${ }^{1}$ \\ ${ }^{1}$ Institute of Problems of Chemical Physics, Russian Academy of Sciences, \\ Chernogolovka, Moscow Region 142432, Russian Federation \\ ${ }^{2}$ Institute of Experimental Mineralogy, Russian Academy of Sciences, \\ Chernogolovka, Moscow Region 142432, Russian Federation \\ ${ }^{3}$ Faculty of Geology, Moscow State University, Vorobievy Gory, \\ Moscow 119991, Russian Federation \\ chukanov@icp.ac.ru
}

\begin{abstract}
Crystals of the natural zeolite amicite, ideally $\mathrm{K}_{4} \mathrm{Na}_{4}\left(\mathrm{Al}_{8} \mathrm{Si}_{8} \mathrm{O}_{32}\right) \cdot 10 \mathrm{H}_{2} \mathrm{O}$, were ion-exchanged in the reactions with $0.1 \mathrm{~N}$ aqueous solutions of $\mathrm{AgNO}_{3}, \mathrm{RbNO}_{3}, \mathrm{CsNO}_{3}$ and $\mathrm{Pb}\left(\mathrm{NO}_{3}\right)_{2}$ at $363 \mathrm{~K}$ for $24 \mathrm{~h}$. Under these conditions, $\mathrm{Cs}^{+}$substitutes $\mathrm{K}^{+}$whereas the most part of $\mathrm{Na}^{+}$remains unexchanged; $\mathrm{Rb}^{+}$partly substitutes both $\mathrm{Na}^{+}$and $\mathrm{K}^{+} ; \mathrm{Pb}^{2+}$ and $\mathrm{Ag}^{+}$completely substitute $\mathrm{Na}^{+}$and $\mathrm{K}^{+}$. All the compounds are monoclinic. The Cs- and $\mathrm{Rb}$-substituted samples have unit-cell parameters close to those of initial amicite. The exchange of $\mathrm{Na}^{+}$and $\mathrm{K}^{+}$for $\mathrm{Ag}^{+}$is accompanied by a significant decrease of the unit-cell volume. The unit-cell parameter $c$ of $\mathrm{Pb}$-amicite is nearly threefold larger than the $c$ parameter of initial amicite. Infrared spectra show that framework topology is preserved during the ion exchange. The crystal structures of initial and Cs-exchanged amicites have been solved by direct methods.
\end{abstract}

Keywords: amicite; zeolite; ion exchange; crystal structure; infrared spectroscopy

\section{ЈОНОИЗМЕНУВАЧКИ СВОЈСТВА НА ПРИРОДНИОТ ЗЕОЛИТЕН АМИЦИТ}

Кристали на природниот зеолитен амицит, со идеална формула $\mathrm{K}_{4} \mathrm{Na}_{4}\left(\mathrm{Al}_{8} \mathrm{Si}_{8} \mathrm{O}_{32}\right) \cdot 10 \mathrm{H}_{2} \mathrm{O}$, беа подложени на реакции на јонска измена со $0,1 \mathrm{~N}$ водни раствори на $\mathrm{AgNO}_{3}, \mathrm{RbNO}_{3}, \mathrm{CsNO}_{3}$ и $\mathrm{Pb}\left(\mathrm{NO}_{3}\right)_{2}$ на $363 \mathrm{~K}$ во тек од $24 \mathrm{~h}$. При овие услови $\mathrm{Cs}^{+}$го заменува $\mathrm{K}^{+}$, додека во најголем дел $\mathrm{Na}^{+}$ останува неизменет; $\mathrm{Rb}^{+}$делумно ги заменува и $\mathrm{Na}^{+}$и $\mathrm{K}^{+} ; \mathrm{Pb}^{2+}$ и $\mathrm{Ag}^{+}$целосно ги заменуваат $\mathrm{Na}^{+}$и $\mathrm{K}^{+}$. Супституираните примероци со Cs и $\mathrm{Rb}$ имаат единични ќелиски параметри блиску до оние на почетниот амицит. Размената на $\mathrm{Na}^{+}$и $\mathrm{K}^{+}$со $\mathrm{Ag}^{+}$е придружена со значајно намалување на волуменот на единичната ќелија. Параметарот $c$ на единичната ќелија на $\mathrm{Pb}$-амицит е речиси три пати поголем од истиот параметар кај почетниот амицит. Инфрацрвените спектри покажуваат дека топологијата на решетката е зачувана за време на јонската измена. Кристалните структури на почетните и со Сs изменети амицити беа решени со директни методи.

Клучни зборови: амицит; зеолит; јонска измена; кристална структура; инфрацрвена спектроскопија

\section{INTRODUCTION}

The rare zeolite-group mineral amicite, ideally $\mathrm{K}_{4} \mathrm{Na}_{4}\left(\mathrm{Al}_{8} \mathrm{Si}_{8} \mathrm{O}_{32}\right) \cdot 10 \mathrm{H}_{2} \mathrm{O}$, was discovered as pseudo-tetragonal dipyramidal crystals, up to 5 $\mathrm{mm}$ across, in a hydrothermal assemblage related to melilite nephelinites of the Höwenegg paleovolcano, Hegau, SW Germany [1]. Amicite is characterized by the same framework topology as gismondine, $\mathrm{Ca}_{4}\left(\mathrm{Al}_{8} \mathrm{Si}_{8} \mathrm{O}_{32}\right) \cdot 18 \mathrm{H}_{2} \mathrm{O}$, which is com- 
posed of double crankshaft tetrahedral chains with ordered $\mathrm{Si}, \mathrm{Al}$ and $\mathrm{Na}, \mathrm{K}$ distributions, space group $I 2$ and unit-cell parameters $a=10.226(1) \AA, b=$ 10.422(1) $\AA, c=9.884(1) \AA$ and $\beta=88.19(1)^{\circ}$ [2]. Later amicite was found in several peralkaline pegmatites in the Khibiny alkaline complex, Kola Peninsula, Russia as pseudotetragonal dipyramidal crystals up to $8 \mathrm{~mm}$ across, as well as simple and polysynthetic contact twins on (110) [3, 4].

Garronite $\mathrm{NaCa}_{2.5}\left(\mathrm{Al}_{6} \mathrm{Si}_{10} \mathrm{O}_{32}\right) \cdot 14 \mathrm{H}_{2} \mathrm{O}$ and gobbinsite $\mathrm{Na}_{5}\left(\mathrm{Al}_{5} \mathrm{Si}_{11} \mathrm{O}_{32}\right) \cdot 12 \mathrm{H}_{2} \mathrm{O}$ are two other minerals belonging to this subgroup of natural zeolites. They have the same framework topology as amicite and gismondine, but $\mathrm{Si}$ and $\mathrm{Al}$ in their crystal structures are essentially disordered $[5,6]$.

Crystals of natural gismondine were ionexchanged in reactions with solutions containing $\mathrm{Ag}, \mathrm{Cs}, \mathrm{Ba}, \mathrm{Li}, \mathrm{Na}, \mathrm{K}$ and $\mathrm{Rb}$ at $368 \mathrm{~K}$ [7]. Crystal structures of the ion-exchanged samples were examined using the Rietveld powder refinement method because single crystals broke into tiny pieces during cation-exchange experiments. The $\mathrm{Ag}$ - and $\mathrm{Cs}, \mathrm{Na}-\mathrm{exchanged}$ gismondines preserved the space group $P 2_{1} / c$ of the original crystals. The symmetry of other samples changed to $P 2_{1}$ (Bagismondine), I2/a (Li-, Na- and $\mathrm{Rb}$-gismondines), or $I 2$ (K-gismondine).

The zeolite MAP ("Maximum Aluminium $\mathrm{P}$ " where "P" denotes "zeolite $\mathrm{P}$ " = gismondine), $\mathrm{Na}_{8}\left(\mathrm{Al}_{8} \mathrm{Si}_{8} \mathrm{O}_{32}\right) \cdot n \mathrm{H}_{2} \mathrm{O}$, the synthetic analogue of amicite in which $\mathrm{K}^{+}$is substituted by $\mathrm{Na}^{+}$, is used as a commercial detergent builder [8,9]. In this microporous material, $\mathrm{Si}$ and $\mathrm{Al}$ are completely ordered. MAP exhibits a high framework flexibility and a high intrinsic thermodynamic selectivity for $\mathrm{Ca}^{2+}$ over $\mathrm{Na}^{+}$[8]. Exchanges of $\mathrm{Na}^{+}$by $\mathrm{Li}^{+}, \mathrm{K}^{+}, \mathrm{Rb}^{+}$, $\mathrm{Cs}^{+}, \mathrm{Mg}^{2+}, \mathrm{Ca}^{2+}, \mathrm{Sr}^{2+}$, and $\mathrm{Ba}^{2+}$ in MAP have been examined [9]. Structural data showed that cation exchange often caused changes in symmetry.

Amicite is characterized by a fairly high degree of framework flexibility; its dehydration in vacuum for $56 \mathrm{~h}$ or 6 days resulted in the removal of two-thirds of the water molecules or complete dehydration, accompanied by a strong decrease in the unit cell volume (11.3\%), respectively [10]. Dehydrated amicite preserves original symmetry and framework topology, but sites of the extraframework cations split into half-occupied subsites. Unlike amicite, complete dehydration of gismondine and garronite is accompanied by destruction of the structure.

In this paper, we report the crystal structure of natural amicite (initial sample from the Kukisvumchorr Mountain, Khibiny), its cation-exchange properties and crystal structure of the Csexchanged form of this zeolite determined from single-crystal X-ray diffraction data.

\section{EXPERIMENTAL SECTION}

Fragments of amicite single crystals from 0.4 to $1 \mathrm{~mm}$ across were used in ion-exchange experiments. They were placed in closed Teflon vessels, mixed with $50 \mathrm{mg}$ of $0.1 \mathrm{M}$ solutions of $\mathrm{Ag}$ $\mathrm{NO}_{3}, \mathrm{RbNO}_{3}, \mathrm{CsNO}_{3}$, or $\mathrm{Pb}\left(\mathrm{NO}_{3}\right)_{2}$, and heated at $363 \mathrm{~K}$ for $24 \mathrm{~h}$. The products were carefully washed free from entrained salts with distilled water and dried at $60{ }^{\circ} \mathrm{C}$ before further investigation.

In order to obtain infrared (IR) absorption spectra, powdered samples were mixed with anhydrous $\mathrm{KBr}$, pelletized, and analyzed using an ALPHA Fourier transform IR spectrometer (Bruker Optics) with a resolution of $4 \mathrm{~cm}^{-1}$. Sixteen scans were collected for each spectrum. The IR spectrum of an analogous pellet of pure $\mathrm{KBr}$ was used as a reference.

Chemical composition was studied using a digital scanning electron microscope Tescan VEGA-II XMU with an energy-dispersive spectrometer INCA Energy 450. Data reduction was carried out by the INCA Energy 300 software package. The analyses were carried out at an accelerating voltage of $20 \mathrm{kV}$. The beam current measured on a reference sample of cobalt was 510-520 pA, and on the studied polished samples, it ranged from 150 to $400 \mathrm{pA}$ (depending on the micro-relief, structure, and composition of samples). The size of the electronic beam varied from 157 to $180 \mathrm{~nm}$ in analytical mode and up to $60 \mathrm{~nm}$ in scanning mode. The excitation zone reached $4-5 \mu \mathrm{m}$. The sample-to-detector distance was $25 \mathrm{~mm}$. The standards used are albite for $\mathrm{Na}, \mathrm{Al}_{2} \mathrm{O}_{3}$ for $\mathrm{Al}, \mathrm{SiO}_{2}$ for $\mathrm{Si}$, sanidine for $\mathrm{K}, \mathrm{PbTe}$ for $\mathrm{Pb}$, pure $\mathrm{Ag}$ for $\mathrm{Ag}$, and synthetic $\mathrm{Rb}_{2} \mathrm{ReCl}_{6}$ and $\mathrm{Cs}_{2} \mathrm{ReCl}_{6}$ for $\mathrm{Rb}$ and $\mathrm{Cs}$, respectively. Water content was determined by weight loss upon heating to $800^{\circ} \mathrm{C}$.

Single-crystal X-ray diffraction (XRD) studies of initial amicite and its Cs-exchanged form were carried out on an Xcalibur diffractometer at $100 \mathrm{~K}$ using $\mathrm{MoK} \alpha$ radiation. The crystal structures were solved by direct methods, followed by the Fourier difference synthesis, and refined by the full-matrix least squares method in an anisotropic approximation for all non-hydrogen atoms using SHELX-97 [11]. Coordinates of $\mathrm{H}$ atoms were not localized. Other details of data collection and structure refinement are given in Tables 1 and 2 . 


\section{Table 1}

Crystal data, data collection information and structure refinement details for initial amicite

\begin{tabular}{|c|c|}
\hline Formula & $\mathrm{K}_{4} \mathrm{Na}_{4}\left(\mathrm{Al}_{8} \mathrm{Si}_{8} \mathrm{O}_{32}\right) \cdot 11 \mathrm{H}_{2} \mathrm{O}$ \\
\hline Formula weight & 1399.09 \\
\hline Temperature, $\mathrm{K}$ & $100(2)$ \\
\hline Radiation and wavelength, $\AA$ & 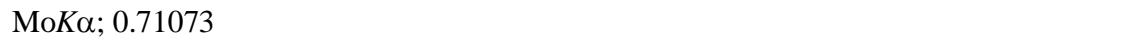 \\
\hline Crystal system, space group, $Z$ & Monoclinic, $I 2,1$ \\
\hline Unit cell dimensions & $a=9.8424(5) \AA, b=10.4488(5) \AA, c=10.1917(5) \AA, \beta=91.816(5)^{\circ}, V=1047.59(9) \AA^{3}$ \\
\hline Density, $\mathrm{g} / \mathrm{cm}^{3}$ & 2.218 (involving non-localized $\mathrm{H}$ atoms) \\
\hline Absorption coefficient $\mu, \mathrm{mm}^{-1}$ & 0.992 \\
\hline Crystal size, $\mathrm{mm}$ & $0.13 \times 0.12 \times 0.10$ \\
\hline Diffractometer & XCaliburS CCD \\
\hline $2 \theta$ range for data collection, ${ }^{\circ}$ & $7.80-68.14$ \\
\hline$h, k, l$ ranges & $-15 \rightarrow 15,-16 \rightarrow 16,-16 \rightarrow 5$ \\
\hline Reflections collected & 4211 \\
\hline Independent reflections & $3433\left(R_{\text {int }}=0.0225\right)$ \\
\hline Independent reflections with $I>4 \sigma(I)$ & 3212 \\
\hline Data reduction & $\begin{array}{l}\text { CrysAlis PRO, version 1.171.36.20, Agilent Technologies Ltd (Agilent Technologies } \\
\text { 2012) [12] }\end{array}$ \\
\hline Absorption correction & $\begin{array}{l}\text { Empirical absorption correction using spherical harmonics, implemented in SCALE3 } \\
\text { ABSPACK scaling algorithm. }\end{array}$ \\
\hline Structure solution & Direct methods \\
\hline Refinement method & Full-matrix least-squares on $F^{2}$ \\
\hline Number of refined parameters & 156 \\
\hline Final $R$ indices $[I>4 \sigma(I)]$ & $R 1=0.037, \mathrm{w} R 2=0.085$ \\
\hline$R$ indices (all data) & $R 1=0.041, \mathrm{w} R 2=0.089$ \\
\hline GoF & 1.075 \\
\hline Largest diff. peak and hole, e/ $/ \AA^{3}$ & 0.706 and -0.669 \\
\hline
\end{tabular}

T a b le 2

Crystal data, data collection information and structure refinement details for Cs-exchanged amicite

\begin{tabular}{|c|c|}
\hline Formula & $\mathrm{Cs}_{3.7} \mathrm{Na}_{3.6}\left(\mathrm{H}_{3} \mathrm{O}\right)_{0.7}\left(\mathrm{Al}_{8} \mathrm{Si}_{8} \mathrm{O}_{32}\right) \cdot 7.2 \mathrm{H}_{2} \mathrm{O}$ \\
\hline Formula weight & 1670.12 \\
\hline Temperature, $\mathrm{K}$ & $100(2)$ \\
\hline Radiation and wavelength, $\AA$ & $\operatorname{MoK\alpha } ; 0.71073$ \\
\hline Crystal system, space group, $Z$ & Monoclinic, $P 2_{1}, 1$ \\
\hline Unit cell dimensions & $a=10.0349(3) \AA, \quad b=10.0534(4) \AA, c=10.0586(4) \AA, \beta=90.474(3)^{\circ}, V=1014.73(6) \AA^{3}$ \\
\hline Density, $\mathrm{g} / \mathrm{cm}^{3}$ & 2.733 (involving non-localized $\mathrm{H}$ atoms) \\
\hline Absorption coefficient $\mu, \mathrm{mm}^{-1}$ & 3.869 \\
\hline Crystal size, mm & $0.15 \times 0.12 \times 0.10$ \\
\hline Diffractometer & XCaliburS CCD \\
\hline $2 \theta$ range for data collection, ${ }^{\circ}$ & $5.71-68.14$ \\
\hline$h, k, l$ ranges & $-15 \rightarrow 15,-15 \rightarrow 12,-15 \rightarrow 15$ \\
\hline Reflections collected & 14299 \\
\hline Independent reflections & $6067\left(R_{\text {int }}=0.0372\right)$ \\
\hline Independent reflections with $I>4 \sigma(I)$ & 5639 \\
\hline Data reduction & $\begin{array}{l}\text { Crys Alis PRO, version 1.171.36.20, Agilent Technologies Ltd (Agilent Technologies, } \\
\text { 2012) [12] }\end{array}$ \\
\hline Absorption correction & $\begin{array}{l}\text { Empirical absorption correction using spherical harmonics, implemented in SCALE3 AB- } \\
\text { SPACK scaling algorithm. }\end{array}$ \\
\hline Structure solution & Direct methods \\
\hline Refinement method & Full-matrix least-squares on $F^{2}$ \\
\hline Number of refined parameters & 297 \\
\hline Final $R$ indices $[I>4 \sigma(I)]$ & $R 1=0.053, \mathrm{w} R 2=0.146$ \\
\hline$R$ indices (all data) & $R 1=0.058, \mathrm{w} R 2=0.148$ \\
\hline GoF & 1.134 \\
\hline Largest diff. peak and hole, e/ $\AA^{3}$ & 2.100 and -1.221 \\
\hline
\end{tabular}




\section{RESULTS AND DISCUSSION}

Chemical data for initial amicite and its ionexchanged forms are given in Table 3 . They correspond to the following empirical formulae, calculated on the basis of $16 \mathrm{Si}+\mathrm{Al}$ atoms per formula unit:

initial amicite, $\mathrm{H}_{20.20} \mathrm{Na}_{3.62} \mathrm{~K}_{4.06}\left(\mathrm{Al}_{7.71} \mathrm{Si}_{8.29} \mathrm{O}_{32}\right) \mathrm{O}_{10.09}$; Cs-amicite, $\mathrm{H}_{16.45} \mathrm{Na}_{3.445} \mathrm{Cs}_{4.19}\left(\mathrm{Al}_{8.10} \mathrm{Si}_{7.90} \mathrm{O}_{32}\right) \mathrm{O}_{8.00}$; Rb-amicite, $\mathrm{H}_{8.64} \mathrm{Na}_{0.77} \mathrm{~K}_{0.44} \mathrm{Rb}_{6.55}\left(\mathrm{Al}_{7.86} \mathrm{Si}_{8.14} \mathrm{O}_{32}\right) \mathrm{O}_{4.27}$; $\mathrm{Pb}$-amicite, $\mathrm{H}_{30.95} \mathrm{~Pb}_{3.98}\left(\mathrm{Al}_{7.89} \mathrm{Si}_{8.11} \mathrm{O}_{32}\right) \mathrm{O}_{15.51}$; Ag-amicite, $\mathrm{H}_{27.90} \mathrm{Ag}_{8.00}\left(\mathrm{Al}_{7.96} \mathrm{Si}_{8.04} \mathrm{O}_{32}\right) \mathrm{O}_{13.97}$.

As seen from these data, $\mathrm{Cs}^{+}$substitutes $\mathrm{K}^{+}$, whereas most $\mathrm{Na}^{+}$remains unexchanged. $\mathrm{Rb}^{+}$substi- tutes both $\mathrm{Na}^{+}$and $\mathrm{K}^{+}$, but a minor part of these cations is preserved. $\mathrm{Pb}^{2+}$ and $\mathrm{Ag}^{+}$completely substitute $\mathrm{Na}$ and $\mathrm{K}$. The reaction with $\mathrm{Rb}^{+}$is accompanied by partial dehydration, whereas reactions with $\mathrm{Pb}^{2+}$ and $\mathrm{Ag}^{+}$are accompanied by additional hydration.

$\mathrm{Rb}-, \mathrm{Pb}-$ and Ag-amicites are chemically homogeneous. The reaction of amicite with $\mathrm{CsNO}_{3}$ solution under the above-described conditions is completed only in the smallest particles, whereas only peripheral parts and zones near cracks are substituted in larger particles (light zones in Fig. 1a), indicating a frontal mechanism of the reaction. The border between cation-exchanged and unexchanged zones is sharp.

T a ble 3

Chemical composition of amicite and its ion-exchanged forms (in wt.\%)

\begin{tabular}{cccccc}
\hline \hline Component & Initial amicite & Cs-amicite & Rb-amicite & Pb-amicite & Ag-amicite \\
\hline $\mathrm{Na}_{2} \mathrm{O}$ & 8.07 & 6.05 & 1.48 & 0 & 0 \\
$\mathrm{~K}_{2} \mathrm{O}$ & 13.77 & 0 & 1.28 & 0 & 0 \\
$\mathrm{Al}_{2} \mathrm{O}_{3}$ & 28.28 & 23.39 & 24.73 & 19.32 & 19.53 \\
$\mathrm{SiO}_{2}$ & 35.85 & 28.69 & 30.15 & 23.42 & 23.25 \\
$\mathrm{H}_{2} \mathrm{O}$ & 13.10 & 8.40 & 4.80 & 13.40 & 12.10 \\
\hline Total & 99.07 & $99.98^{\mathrm{a})}$ & $100.20^{\mathrm{b}}$ & $98.85^{\mathrm{c}}$ & $99.48^{\mathrm{d})}$ \\
\hline \hline
\end{tabular}

The total includes a) 33.45 wt. \% $\mathrm{Cs}_{2} \mathrm{O}$, b) 37.76 wt. \% $\mathrm{Rb}_{2} \mathrm{O}$, c) 42.71 wt. \% $\mathrm{PbO}$, d) 44.60 wt. \% $\mathrm{Ag}_{2} \mathrm{O}$

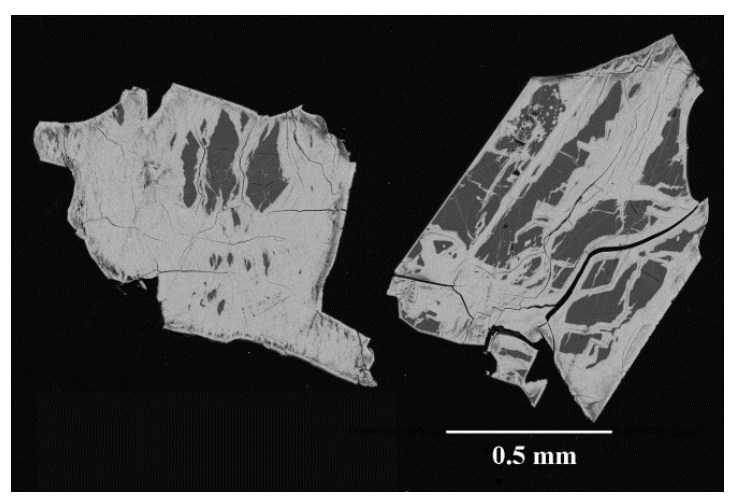

a

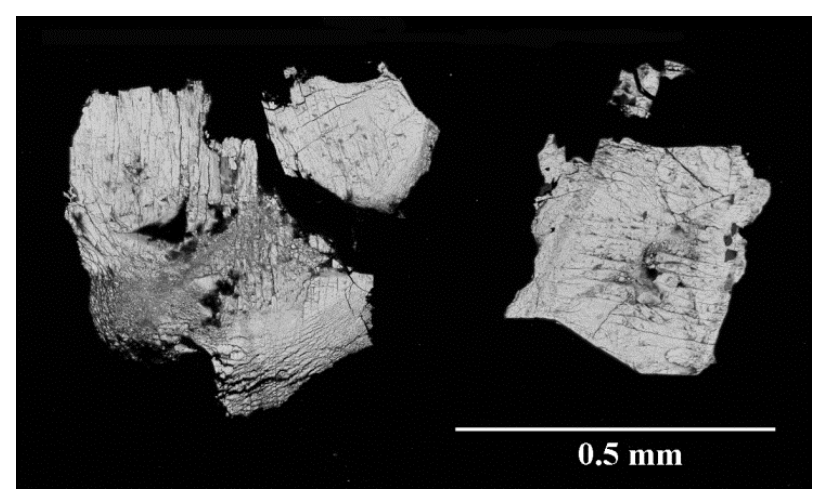

c

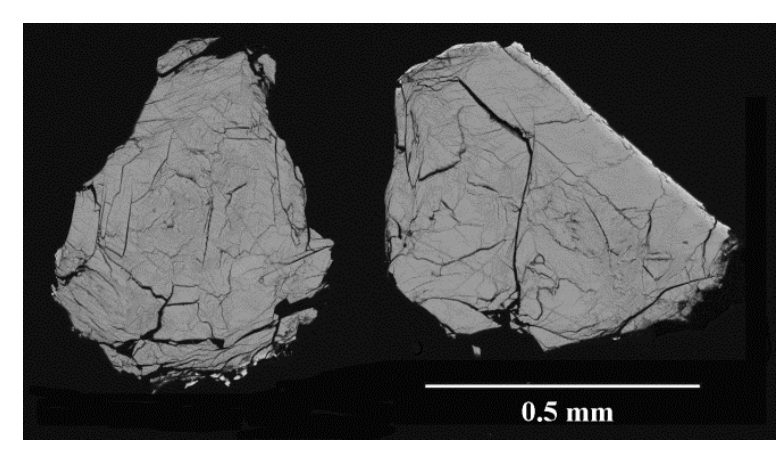

b

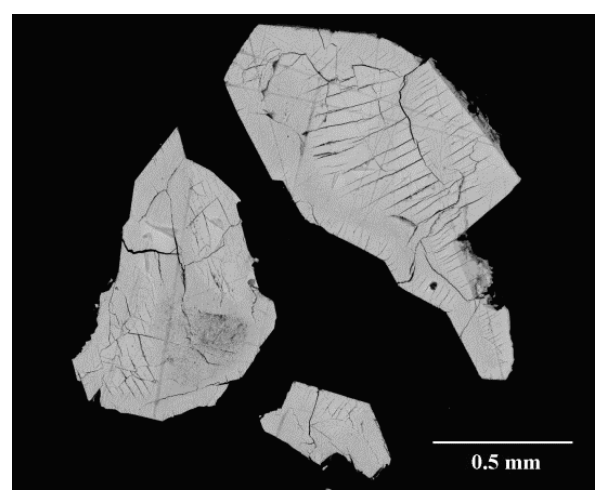

$\mathrm{d}$

Fig. 1. Products of ion-exchange reactions of amicite with aqueous solutions of $\mathrm{CsNO}_{3}(\mathrm{a}), \mathrm{RbNO}_{3}(\mathrm{~b})$, $\mathrm{Pb}\left(\mathrm{NO}_{3}\right)_{2}$ (c) and $\mathrm{AgNO}_{3}(\mathrm{~d})$. SEM (BSE) images of polished sections are shown. 
In the course of ion-exchange processes, single crystals crack due to internal strains (Figs. $1 \mathrm{a}-\mathrm{c})$. This results in significant distortions of single-crystal XRD patterns and makes the determination of the crystal structures impossible using single-crystal data for all ion-exchanged samples, except Cs-amicite.

The IR spectra of initial amicite and its ion exchange products (Fig. 2) in the range from 360 to $1200 \mathrm{~cm}^{-1}$, corresponding to vibrations of the tetrahedral Al-Si-O framework, are rather similar, indicating possible preservation of the framework topology. Bands in the structure-sensitive range, $500-800 \mathrm{~cm}^{-1}$, in the IR spectrum of $\mathrm{Pb}$-amicite are poorly resolved compared with IR spectra of other samples. The most significant differences between the IR spectra of amicite and its cationexchanged forms are observed in the range of vibrations of $\mathrm{H}_{2} \mathrm{O}$ molecules $\left(1500-3800 \mathrm{~cm}^{-1}\right)$. In particular, the IR spectra confirm a high degree of $\mathrm{Pb}$-amicite hydration and a low degree of $\mathrm{Rb}$ amicite hydration.

Three distinct bands (at 1590, 1648, 1699 $\mathrm{cm}^{-1}$ ) and a shoulder above $1700 \mathrm{~cm}^{-1}$ which correspond to nondegenerate $\mathrm{H}-\mathrm{O}-\mathrm{H}$ bending modes of $\mathrm{H}_{2} \mathrm{O}$ in the IR spectrum of initial amicite indicate the presence of numerous (at least four) locally different water molecules. This is in good agreement with structural data (see below). In particular, the band of $\mathrm{O}-\mathrm{H}$ stretching vibrations at $3136 \mathrm{~cm}^{-1}$ corresponds to $\mathrm{H}_{2} \mathrm{O}$ molecules forming strong hydrogen bonds. Bands of $\mathrm{H}-\mathrm{O}-\mathrm{H}$ bending and $\mathrm{O}-\mathrm{H}$ stretching vibrations in the IR spectra of all ion-exchanged amicites are split, though to a less extent, and broadened (possibly as a result of overlap of numerous close bands), which may correspond to the presence of multiple states of $\mathrm{H}_{2} \mathrm{O}$ molecules forming hydrogen bonds of medium strengths.

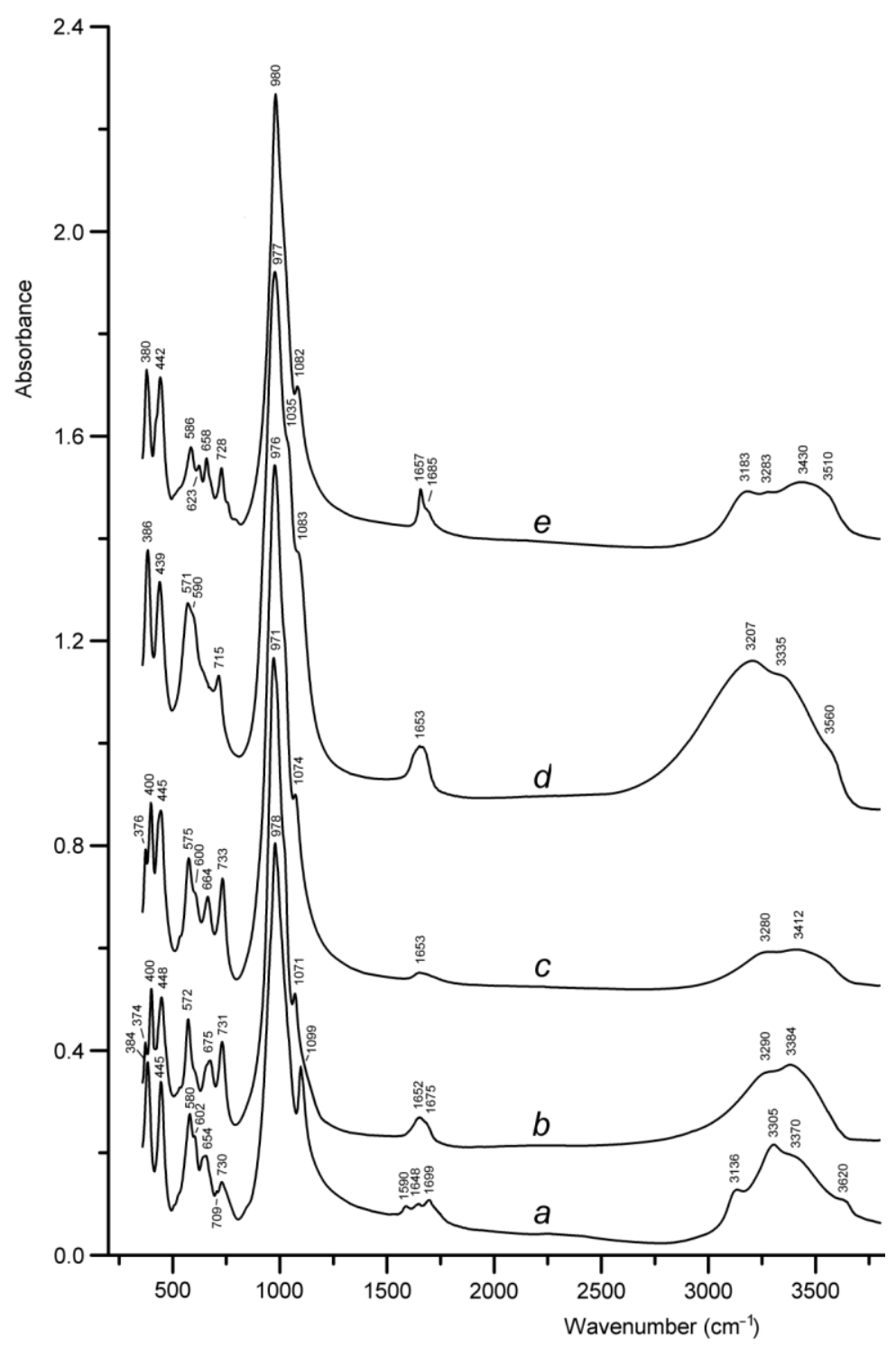

Fig. 2. IR spectra of initial amicite (a), Ag-amicite (b), Rb-amicite (c), Pb-amicite (d), Cs-amicite $(e)$. 
The unit-cell parameters of amicite and its ion-exchanged forms, determined from singlecrystal XRD data, are given in Table 4. All the compounds are monoclinic. The Cs- and $\mathrm{Rb}-$ substituted samples have unit-cell parameters which are close to those of initial amicite, but the exchange of $\mathrm{Na}$ and $\mathrm{K}$ for $\mathrm{Ag}$ is accompanied by a significant (more than $8 \%$ ) decrease of the unit- cell volume. A similar contraction of the unit cell was observed in the ion-exchange reaction of gismondine with $\mathrm{Ag}^{+}$[7], as well. The unit-cell parameter, $c$, of $\mathrm{Pb}$-amicite is nearly threefold larger than the $c$ parameter of initial amicite, which, together with IR spectroscopy data, indicates an essential change of the crystal structure as a result of the reaction with $\mathrm{Pb}\left(\mathrm{NO}_{3}\right)_{2}$.

Ta ble 4

Unit-cell parameters of amicite and its ion-exchanged forms

\begin{tabular}{cccccc}
\hline \hline Compound & Initial amicite & Cs-amicite & Rb-amicite & Pb-amicite & Ag-amicite \\
\hline$a(\AA)$ & $9.8424(5)$ & $10.0349(3)$ & $10.043(2)$ & $9.8571(5)$ & $9.272(2)$ \\
$b(\AA)$ & $10.4488(5)$ & $10.0534(4)$ & $9.748(2)$ & $10.6079(5)$ & $9.997(2)$ \\
$c(\AA)$ & $10.1917(5)$ & $10.0586(4)$ & $10.265(2)$ & $29.453(2)$ & $10.380(3)$ \\
$\beta\left(\left(^{\circ}\right)\right.$ & $91.816(5)$ & $90.474(3)$ & $90.09(3)$ & $90.756(5)$ & $90.821(8)$ \\
$V\left(\AA^{3}\right)$ & $1047.59(9)$ & $1014.72(6)$ & $1005.0(3)$ & $3079.4(3)$ & $962.0(4)$ \\
\hline \hline
\end{tabular}

The crystal structure of initial amicite from Kukisvumchorr (Tables 5 and 6, Figs. 3 and 4) is generally the same as that of amicite from its type locality, Höwenegg [2]. In both samples, $\mathrm{Si}$ and $\mathrm{Al}$ atoms, as well as $\mathrm{Na}^{+}$and $\mathrm{K}^{+}$ions, are ordered. The coordination polyhedron of the $\mathrm{Na}$ atom can be described as a distorted one-cap trigonal antiprism. The coordination polyhedron of $\mathrm{K}^{+}$can be repre- sented as a distorted hexagonal pyramid, with one of the apical vertices replaced by two $\mathrm{O}$ atoms. In the channel running along (001) (Fig. 4), $\mathrm{Na}^{+}$ions are attached to its walls, whereas $\mathrm{K}^{+}$ions are shifted towards its centrum. Perhaps due to this feature, only $\mathrm{K}^{+}$ions are involved in the reaction with $\mathrm{Cs}^{+}$, whereas $\mathrm{Na}^{+}$ions remain unchanged.

Table 5

Fractional atomic coordinates, site multiplicities $(Q)$ and equivalent isotropic atom displacement parameters $\left(U_{e q}\right)$ in the crystal structure of initial amicite

\begin{tabular}{cccccc}
\hline \hline Site & $x / a$ & $y / b$ & $z / c$ & $U_{\text {eq }}, \AA^{2}$ & $Q$ \\
\hline $\mathrm{K}$ & $0.53085(7)$ & $0.26211(8)$ & $0.30426(8)$ & $0.0108(1)$ & 4 \\
$\mathrm{Na}$ & $0.6738(2)$ & $0.5057(2)$ & $0.0684(1)$ & $0.0160(3)$ & 4 \\
$\mathrm{Si}(1)$ & $0.17503(9)$ & $0.27238(9)$ & $0.15322(9)$ & $0.0034(2)$ & 4 \\
$\mathrm{Si}(2)$ & $0.32452(9)$ & $-0.00240(9)$ & $-0.15386(8)$ & $0.0034(2)$ & 4 \\
$\mathrm{Al}(1)$ & $-0.15163(9)$ & $0.2566(1)$ & $0.1588(1)$ & $0.0036(2)$ & 4 \\
$\mathrm{Al}(2)$ & $0.34434(9)$ & $0.0104(1)$ & $0.15434(9)$ & $0.0037(2)$ & 4 \\
$\mathrm{O}(1)$ & $0.4824(2)$ & $0.0314(2)$ & $-0.1688(2)$ & $0.0065(5)$ & 4 \\
$\mathrm{O}(2)$ & $0.2803(2)$ & $-0.1224(2)$ & $-0.2459(2)$ & $0.0056(5)$ & 4 \\
$\mathrm{O}(3)$ & $0.0220(2)$ & $0.2293(2)$ & $0.1837(3)$ & $0.0075(5)$ & 4 \\
$\mathrm{O}(4)$ & $0.2202(2)$ & $0.3980(2)$ & $0.2375(2)$ & $0.0060(4)$ & 4 \\
$\mathrm{O}(5)$ & $0.1968(3)$ & $0.3042(3)$ & $0.0000(2)$ & $0.0080(5)$ & 4 \\
$\mathrm{O}(6)$ & $0.2358(3)$ & $0.1181(2)$ & $-0.2065(2)$ & $0.0064(4)$ & 4 \\
$\mathrm{O}(7)$ & $0.2758(2)$ & $0.1570(2)$ & $0.2023(2)$ & $0.0060(4)$ & 4 \\
$\mathrm{O}(8)$ & $0.2889(2)$ & $-0.0364(2)$ & $-0.0033(2)$ & $0.0066(4)$ & 4 \\
$\mathrm{OW} 1$ & 0.5 & $0.4334(4)$ & 0.5 & $0.0137(7)$ & 2 \\
$\mathrm{OW} 2$ & $0.7156(3)$ & $0.1899(3)$ & $0.5216(3)$ & $0.0125(5)$ & 4 \\
$\mathrm{OW} 3$ & $0.4540(3)$ & $0.5085(3)$ & $0.1546(3)$ & $0.0152(5)$ & 4 \\
$\mathrm{OW} 4$ & 0.5 & $0.2835(8)$ & 0 & $0.019(2)$ & 2 \\
\hline \hline
\end{tabular}

The OW4 site occupancy factor is $0.49(1)$ 
Table 6

Selected interatomic distances $(\AA)$ in the crystal structure of initial amicite ${ }^{\mathrm{a}}$

\begin{tabular}{ccccc}
\hline \hline \multicolumn{2}{c}{$T$-tetrahedra } & \multicolumn{2}{c}{ K- and Na-polyhedra } \\
\hline $\mathrm{Si}(1)-\mathrm{O}(3)$ & $1.612(3)$ & & $\mathrm{K}-\mathrm{OW} 1$ & $2.704(3)$ \\
$-\mathrm{O}(5)$ & $1.618(3)$ & & $-\mathrm{O}(1) \# 3$ & $2.779(3)$ \\
$-\mathrm{O}(4)$ & $1.623(3)$ & & $-\mathrm{O}(2) \# 5$ & $2.798(3)$ \\
$-\mathrm{O}(7)$ & $1.630(3)$ & & $-\mathrm{O}(7)$ & $2.902(3)$ \\
$\mathrm{Si}(2)-\mathrm{O}(1)$ & $1.605(2)$ & & $-\mathrm{OW} 2$ & $2.920(3)$ \\
$-\mathrm{O}(6)$ & $1.614(3)$ & & $-\mathrm{O}(6) \# 3$ & $2.945(3)$ \\
$-\mathrm{O}(2)$ & $1.618(3)$ & & $-\mathrm{OW} 3$ & $3.075(3)$ \\
$-\mathrm{O}(8)$ & $1.624(3)$ & & $-\mathrm{OW} 4$ & $3.114(1)$ \\
$\mathrm{Al}(1)-\mathrm{O}(5) \# 1$ & $1.738(3)$ & & $-\mathrm{OW} 2 \# 6$ & $3.143(3)$ \\
$-\mathrm{O}(2) \# 2$ & $1.740(3)$ & & $\mathrm{Na}-\mathrm{OW}(4)$ & $3.419(3)$ \\
$-\mathrm{O}(3)$ & $1.743(2)$ & & $-\mathrm{OW} 2 \# 7$ & $2.361(3)$ \\
$-\mathrm{O}(6) \# 1$ & $1.744(3)$ & & $-\mathrm{O}(2) \# 5$ & $2.407(3)$ \\
$\mathrm{Al}(2)-\mathrm{O}(1) \# 3$ & $1.721(2)$ & & $-\mathrm{OW} 3 \# 3$ & $2.520(3)$ \\
$-\mathrm{O}(4) \# 4$ & $1.744(3)$ & & $-\mathrm{O}(5) \# 3$ & $2.562(3)$ \\
$-\mathrm{O}(8)$ & $1.750(3)$ & & $-\mathrm{O}(6) \# 5$ & $2.568(3)$ \\
$-\mathrm{O}(7)$ & $1.749(3)$ & & $-\mathrm{OW} 4$ & $2.632(3)$ \\
\hline \hline
\end{tabular}

aThe symmetry transformations used to generate equivalent atoms are: $\# 1-x, y,-z ; \# 2 x-1 / 2, y+1 / 2, z+1 / 2$; \#3 - x+1, $y,-z$; \#4 -x+1/2, $y-1 / 2,-z+1 / 2$; $\# 5 x+1 / 2, y+1 / 2, z+1 / 2 ; \# 6-x+1, y,-z+1 ; \# 7-x+3 / 2, y+1 / 2,-z+1 / 2$.

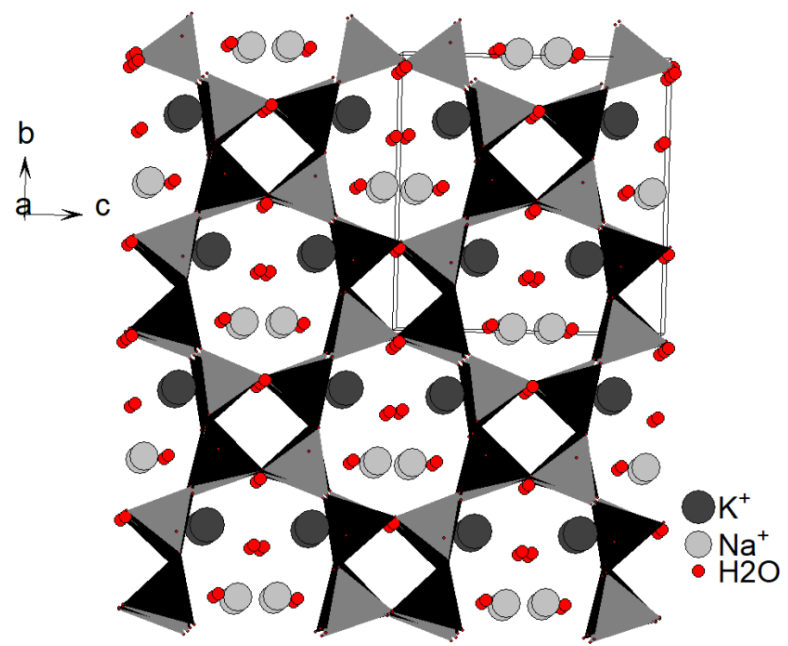

Fig. 3. The crystal structure of initial amicite from Kukisvumchorr: the $b c$ projection. Grey tetrahedra refer to $\mathrm{SiO}_{4}$, black tetrahedra to $\mathrm{AlO}_{4}$.

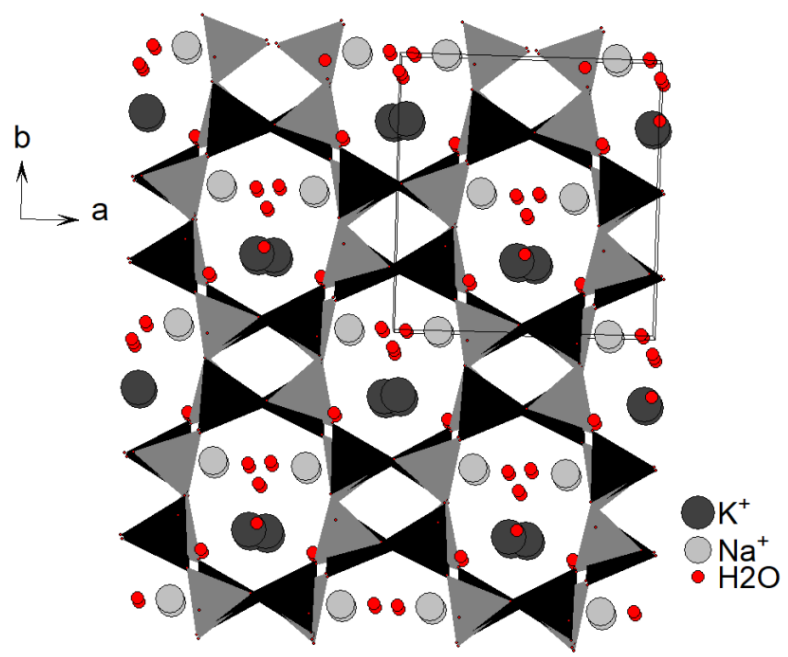

Fig. 4. The crystal structure of initial amicite from Kukisvumchorr: the $a b$ projection. Grey tetrahedra refer to $\mathrm{SiO}_{4}$, black tetrahedra to $\mathrm{AlO}_{4}$. 
In the crystal structure of Cs-substituted amicite from Kukisvumchorr (Tables 7 and 8, Figs. 5 and 6), Na atoms occupy two sites, whose coordination polyhedra are distorted pentagonal pyramids. Cs atoms occupy two sites having 11 -fold coordination. All sites of extra-framework cations contained minor admixtures of $\mathrm{H}_{2} \mathrm{O}$ or $\mathrm{H}_{3} \mathrm{O}$. Unfortunately, $\mathrm{H}_{2} \mathrm{O}$ and $\mathrm{H}_{3} \mathrm{O}$ cannot be distinguished by $\mathrm{X}$-ray structural analysis, but the presence of about $0.45 \mathrm{H}_{3} \mathrm{O}^{+}$cations per formula unit can be supposed based on the charge balance in the empirical formula.

\section{T a ble 7}

Fractional atomic coordinates, site multiplicities $(Q)$ site occupation factors $(q)$ and equivalent isotropic atom displacement parameters $\left(U_{e q}\right)$ in the crystal structure of Cs-substituted amicite

\begin{tabular}{|c|c|c|c|c|c|c|}
\hline Site & $x / a$ & $y / b$ & $z / c$ & $U_{\mathrm{eq}}, \AA^{2}$ & $q$ & $Q$ \\
\hline Cs1 & $-0.09539(7)$ & $0.12630(8)$ & $0.26480(7)$ & $0.0218(2)$ & $\begin{array}{l}\text { Cs1: 0.915(7) } \\
\text { O17: } 0.085(7)\end{array}$ & 2 \\
\hline Cs2 & $0.23769(5)$ & $0.37014(7)$ & $0.41789(7)$ & $0.0189(2)$ & $\begin{array}{l}\text { Cs2: } 0.923(7) \\
\text { O18: } 0.077(7)\end{array}$ & 2 \\
\hline $\mathrm{Na} 1$ & $-0.4596(5)$ & $0.9264(5)$ & $0.1856(5)$ & $0.022(1)$ & $\begin{array}{l}\text { Na1: } 0.90(6) \\
\text { O19: } 0.10(6)\end{array}$ & 2 \\
\hline $\mathrm{Na} 2$ & $0.3311(5)$ & $0.1780(6)$ & $0.0585(6)$ & $0.033(2)$ & $\begin{array}{l}\mathrm{Na2}: 0.88(7) \\
\mathrm{O} 20: 0.12(7)\end{array}$ & 2 \\
\hline Si1 & $0.3864(2)$ & $-0.2695(3)$ & $0.3910(2)$ & $0.0118(4)$ & 1 & 2 \\
\hline $\mathrm{Si} 2$ & $0.1117(2)$ & $0.0325(3)$ & $0.5728(3)$ & $0.0116(4)$ & 1 & 2 \\
\hline $\mathrm{Si} 3$ & $0.0688(2)$ & $-0.2607(3)$ & $0.0739(3)$ & $0.0130(5)$ & 1 & 2 \\
\hline $\mathrm{Si} 4$ & $0.5689(2)$ & $-0.5674(3)$ & $0.1096(3)$ & $0.0115(4)$ & 1 & 2 \\
\hline Al1 & $0.4229(3)$ & $-0.0215(3)$ & $0.5769(3)$ & $0.0111(5)$ & 1 & 2 \\
\hline $\mathrm{Al} 2$ & $0.0783(3)$ & $-0.2158(3)$ & $0.3833(3)$ & $0.0115(5)$ & 1 & 2 \\
\hline $\mathrm{Al} 3$ & $0.3770(3)$ & $-0.3182(3)$ & $0.0751(3)$ & $0.0114(5)$ & 1 & 2 \\
\hline $\mathrm{Al} 4$ & $0.8826(3)$ & $-0.5122(3)$ & $0.1177(3)$ & $0.0129(5)$ & 1 & 2 \\
\hline $\mathrm{O} 1$ & $0.4583(7)$ & $-0.4020(7)$ & $0.4511(7)$ & $0.016(1)$ & 1 & 2 \\
\hline $\mathrm{O} 2$ & $0.2321(7)$ & $-0.2816(9)$ & $0.4286(7)$ & $0.021(1)$ & 1 & 2 \\
\hline $\mathrm{O} 3$ & $0.4557(6)$ & $-0.1400(8)$ & $0.4557(7)$ & $0.017(1)$ & 1 & 2 \\
\hline $\mathrm{O} 4$ & $0.2698(6)$ & $0.0593(8)$ & $0.5518(9)$ & $0.020(1)$ & 1 & 2 \\
\hline $\mathrm{O} 5$ & $0.0498(7)$ & $-0.0629(7)$ & $0.4598(7)$ & $0.017(1)$ & 1 & 2 \\
\hline O6 & $-0.0420(6)$ & $-0.3231(7)$ & $0.4392(8)$ & $0.018(1)$ & 1 & 2 \\
\hline $\mathrm{O} 7$ & $0.0697(9)$ & $-0.1811(8)$ & $0.2138(8)$ & $0.023(1)$ & 1 & 2 \\
\hline $\mathrm{O} 8$ & $-0.0540(7)$ & $-0.3636(9)$ & $0.0581(9)$ & $0.026(2)$ & 1 & 2 \\
\hline O9 & $0.0445(8)$ & $-0.1496(8)$ & $-0.0424(8)$ & $0.023(1)$ & 1 & 2 \\
\hline $\mathrm{O} 10$ & $0.2074(6)$ & $-0.3401(8)$ & $0.0474(7)$ & $0.019(1)$ & 1 & 2 \\
\hline O11 & $0.4121(7)$ & $-0.2602(8)$ & $0.2312(7)$ & $0.017(1)$ & 1 & 2 \\
\hline $\mathrm{O} 12$ & $0.4543(6)$ & $-0.2062(7)$ & $-0.0332(7)$ & $0.014(1)$ & 1 & 2 \\
\hline O13 & $0.4581(8)$ & $-0.4682(7)$ & $0.0461(8)$ & $0.020(1)$ & 1 & 2 \\
\hline $\mathrm{O} 14$ & $0.5524(6)$ & $-0.5923(7)$ & $0.2662(6)$ & $0.014(1)$ & 1 & 2 \\
\hline O15 & $0.7126(7)$ & $-0.5050(8)$ & $0.0789(8)$ & $0.020(1)$ & 1 & 2 \\
\hline O16 & $-0.0833(7)$ & $0.4644(9)$ & $0.2858(8)$ & $0.020(1)$ & 1 & 2 \\
\hline OW1 & $-0.4101(8)$ & $0.1178(9)$ & $0.2787(8)$ & $0.024(1)$ & 1 & 2 \\
\hline OW2 & $0.2178(8)$ & $0.364(1)$ & $0.109(1)$ & $0.034(2)$ & 1 & 2 \\
\hline OW3 & $0.262(1)$ & $0.046(1)$ & $0.239(1)$ & $0.027(3)$ & $0.75(4)$ & 2 \\
\hline OW4 & $-0.2615(9)$ & $-0.199(1)$ & $0.230(1)$ & $0.029(3)$ & $0.83(4)$ & 2 \\
\hline
\end{tabular}


Table 8

Selected interatomic distances (in $\AA$ ) in the crystal structure of Cs-substituted amicite ${ }^{\mathrm{a}}$

\begin{tabular}{|c|c|c|c|}
\hline \multicolumn{4}{|c|}{$T$-tetrahedra } \\
\hline $\mathrm{Si}(1)-\mathrm{O}(2)$ & $1.601(7)$ & $\mathrm{Al}(1)-\mathrm{O}(1) \# 1$ & $1.718(7)$ \\
\hline$-\mathrm{O}(3)$ & $1.611(8)$ & $-\mathrm{O}(3)$ & $1.737(8)$ \\
\hline$-\mathrm{O}(1)$ & $1.629(7)$ & $-\mathrm{O}(14) \# 1$ & $1.747(7)$ \\
\hline$-\mathrm{O}(11)$ & $1.632(8)$ & $-\mathrm{O}(4)$ & $1.754(7)$ \\
\hline $\mathrm{Si}(2)-\mathrm{O}(16) \# 2$ & $1.606(8)$ & $\mathrm{Al}(2)-\mathrm{O}(6)$ & $1.717(7)$ \\
\hline$-\mathrm{O}(5)$ & $1.608(8)$ & $-\mathrm{O}(2)$ & $1.736(7)$ \\
\hline$-\mathrm{O}(6) \# 3$ & $1.616(8)$ & $-\mathrm{O}(7)$ & $1.742(8)$ \\
\hline$-\mathrm{O}(4)$ & $1.625(7)$ & $-\mathrm{O}(5)$ & $1.744(8)$ \\
\hline $\mathrm{Si}(3)-\mathrm{O}(8)$ & $1.615(8)$ & $\mathrm{Al}(3)-\mathrm{O}(11)$ & $1.709(8)$ \\
\hline$-O(7)$ & $1.618(8)$ & $-\mathrm{O}(10)$ & $1.736(7)$ \\
\hline$-\mathrm{O}(10)$ & $1.628(7)$ & $-\mathrm{O}(13)$ & $1.739(8)$ \\
\hline$-\mathrm{O}(9)$ & $1.633(8)$ & $-\mathrm{O}(12)$ & $1.752(7)$ \\
\hline $\mathrm{Si}(4)-\mathrm{O}(14)$ & $1.605(7)$ & $\mathrm{Al}(4)-\mathrm{O}(8) \# 5$ & $1.733(9)$ \\
\hline$-O(15)$ & $1.605(7)$ & $-\mathrm{O}(16) \# 6$ & $1.738(8)$ \\
\hline$-\mathrm{O}(12) \# 4$ & $1.610(8)$ & $-\mathrm{O}(9) \# 4$ & $1.740(8)$ \\
\hline$-\mathrm{O}(13)$ & $1.621(8)$ & $-\mathrm{O}(15)$ & $1.748(8)$ \\
\hline \multicolumn{4}{|c|}{ Cs- and Na-polyhedra } \\
\hline $\mathrm{Cs}(1)-\mathrm{O}(5)$ & $3.089(7)$ & $\mathrm{Cs}(2)-\mathrm{OW} 2$ & $3.11(1)$ \\
\hline -OW1 & $3.164(8)$ & $-\mathrm{O}(6) \# 3$ & $3.120(7)$ \\
\hline$-\mathrm{O}(9) \# 7$ & $3.219(8)$ & $-\mathrm{O}(1) \# 8$ & $3.201(7)$ \\
\hline$-\mathrm{O}(6) \# 3$ & $3.311(8)$ & $-\mathrm{O}(5) \# 3$ & $3.217(7)$ \\
\hline$-\mathrm{O}(10) \# 7$ & $3.344(7)$ & $-\mathrm{O}(3) \# 1$ & $3.321(7)$ \\
\hline$-O(16)$ & $3.408(9)$ & $-\mathrm{O}(4)$ & $3.418(8)$ \\
\hline$-\mathrm{O}(2) \# 3$ & $3.510(8)$ & $-\mathrm{O}(2) \# 8$ & $3.504(9)$ \\
\hline$-\mathrm{O}(7)$ & $3.546(8)$ & $-\mathrm{O}(14) \# 8$ & $3.539(6)$ \\
\hline$-\mathrm{O}(8) \# 7$ & $3.590(9)$ & $-\mathrm{O}(16)$ & $3.601(8)$ \\
\hline -OW4 & $3.68(1)$ & -OW4\#3 & $3.62(1)$ \\
\hline -OW3 & $3.69(1)$ & $-\mathrm{OW} 3$ & $3.74(1)$ \\
\hline $\mathrm{Na}(1)-\mathrm{OW} 1 \# 8$ & $2.20(1)$ & $\mathrm{Na}(2)-\mathrm{OW} 2$ & $2.25(1)$ \\
\hline$-\mathrm{O}(11) \# 9$ & $2.322(9)$ & $-\mathrm{O}(15) \# 11$ & $2.34(1)$ \\
\hline -OW4\#8 & $2.39(1)$ & -OW3 & $2.35(1)$ \\
\hline$-\mathrm{O}(13) \# 10$ & $2.560(9)$ & $-\mathrm{O}(12) \# 11$ & $2.463(8)$ \\
\hline$-\mathrm{O}(12) \# 9$ & $2.708(9)$ & $-\mathrm{O}(13) \# 11$ & $2.79(1)$ \\
\hline$-\mathrm{O}(3) \# 9$ & $2.931(9)$ & $-\mathrm{O}(8) \# 7$ & $3.038(8)$ \\
\hline
\end{tabular}

aThe symmetry transformations used to generate equivalent atoms are:

$\# 1-\mathrm{x}+1, \mathrm{y}+1 / 2,-\mathrm{z}+1 ; \quad \# 2-\mathrm{x}, \mathrm{y}-1 / 2,-\mathrm{z}+1$;

\#3-x, y+1/2,-z+1; \#4-x+1, y-1/2,-z; \#5 x+1, y, z;

$\# 6 \mathrm{x}+1, \mathrm{y}-1, \mathrm{z} ; \# 7-\mathrm{x}, \mathrm{y}+1 / 2,-\mathrm{z} ; \# 8 \mathrm{x}, \mathrm{y}+1, \mathrm{z}$;

$\# 9 \mathrm{x}-1, \mathrm{y}+1, \mathrm{z} ; \# 10-\mathrm{x}, \mathrm{y}+3 / 2,-\mathrm{z} ; \# 11-\mathrm{x}+1, \mathrm{y}+1 / 2,-\mathrm{z}$.

The sizes of the channels of studied amicites are slightly different. In the initial amicite, the minimum diameter of the channel formed by eightmembered rings of the tetrahedra is about $3.3 \AA$ in the projection along the $a$ axis and $2.9 \AA$ in the projection along the $c$ axis; the maximum channel size in both projections is about $5.0 \AA$. For Csamicite, the minimum values of the diameter of the eight-membered channel in different projections are $3.3 \AA$, and the maximum ones are 5.6 $\AA$. Thus, the substitution of $\mathrm{K}$ for $\mathrm{Cs}$ in amicite mainly results in an increase in the larger cross-sectional diameter of the eight-membered channel.
In the structure of Na,Cs-gismondine, refined by the Rietveld method [7], there are multiple Cs sites and a Na site located off center, closer to the wall of the channel. Cs-substituted amicite and $\mathrm{Na}, \mathrm{Cs}$-gismondine have similar unit-cell volumes (1014.7 and 1022.6 $\AA^{3}$, respectively).

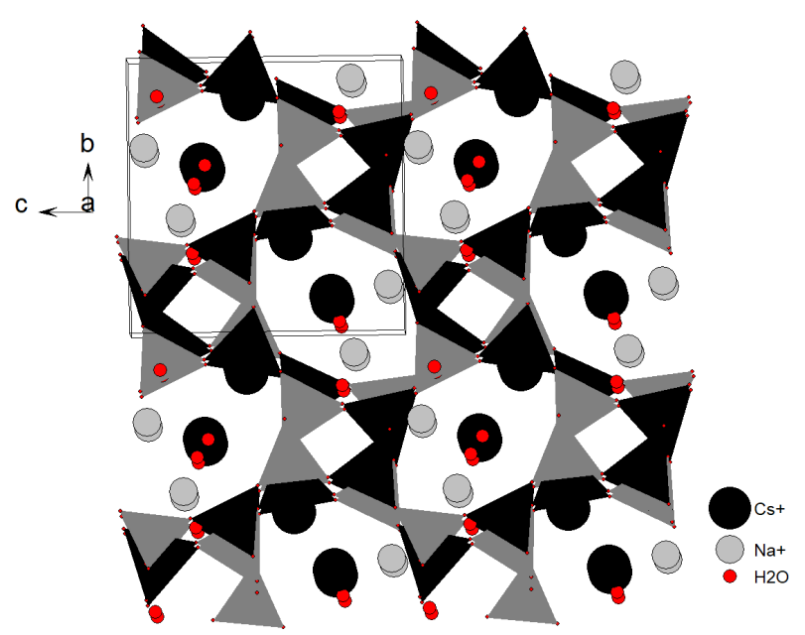

Fig. 5. The crystal structure of Cs-amicite: the $b c$ projection. Grey tetrahedra refer to $\mathrm{SiO}_{4}$, black tetrahedra to $\mathrm{AlO}_{4}$.

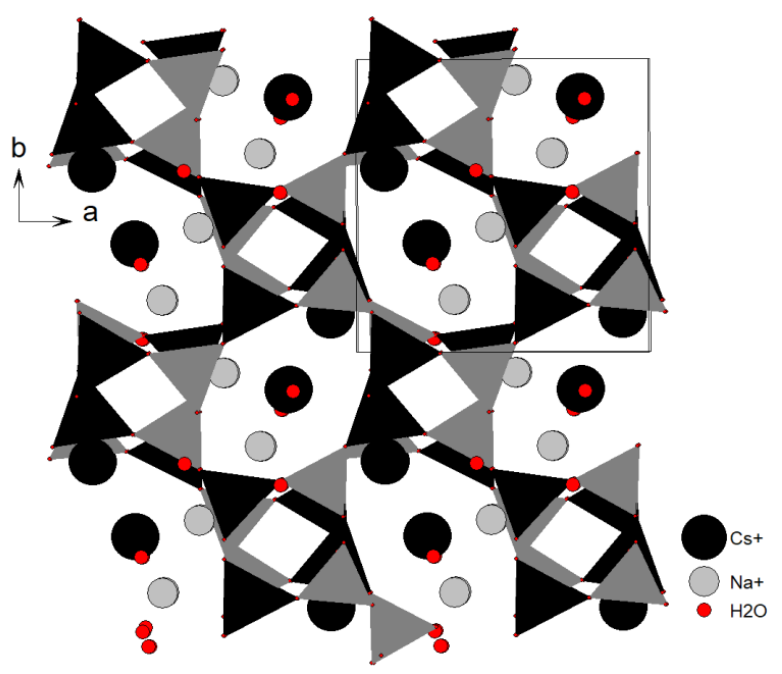

Fig. 6. The crystal structure of Cs-amicite: the $a b$ projection. Grey tetrahedra refer to $\mathrm{SiO}_{4}$, black tetrahedra to $\mathrm{AlO}_{4}$.

\section{CONCLUSIONS}

Amicite shows high activity in ion-exchange reactions with $\mathrm{Ag}^{+}, \mathrm{Rb}^{+}, \mathrm{Cs}^{+}$and $\mathrm{Pb}^{2+}$ under mild conditions. Synthetic analogues of this zeolite and related zeolites with the same framework topology can be used for wastewater purification. The data obtained in this work demonstrate high flexibility of the amicite framework; changes in the unit-cell volume reaching $9 \%$ do not result in framework 
destruction. In the reaction with the largest cation, $\mathrm{Cs}^{+}$, only $\mathrm{K}^{+}$is involved in ion exchange. In contrast, $\mathrm{Ag}^{+}, \mathrm{Rb}^{+}$, and $\mathrm{Pb}^{2+}$ substitute both $\mathrm{K}^{+}$and $\mathrm{Na}^{+}$. This distinction may have a steric nature.

Acknowledgments. This work was carried out in accordance with the state task, state registration number No. AAAA-A19-119092390076-7. Chemical analyses and IR spectroscopic study were supported by the Russian Foundation for Basic Research (grant No. 18-29-12007-mk).

\section{REFERENCES}

[1] A. Alberti, G. Hentschel, G. Vezzalini, Amicite, a new natural zeolite, Neues Jahrbuch für Mineralogie, Monatshefte, 481-488 (1979).

[2] A. Alberti, G. Vezzalini, The crystal structure of amicite, a zeolite, Acta Crystallographica, 35, 2866-2869 (1979). DOI: https://doi.org/10.1107/S0567740879010852

[3] A. P. Khomyakov, G. E. Cherepivskaya, T. A. Kurova, V. V. Kaptsov, Amicite $\mathrm{K}_{2} \mathrm{Na}_{2} \mathrm{Al}_{4} \mathrm{Si}_{4} \mathrm{O}_{16} \cdot 5 \mathrm{H}_{2} \mathrm{O}$ - the first find in the U.S.S.R, Doklady Academii Nauk SSSR. 263, 978-980 (1982) (Russian).

[4] I. V. Pekov, Kukisvumchorr Deposit: Mineralogy of Alkaline Pegmatites and Hydrothermalites, Ocean Picrures Ltd., Littleton (2004).

[5] G. Artioli. The crystal structure of garronite, Americal Mineralogist, 77, 189-196 (1992).

https://pubs.geoscienceworld.org/msa/ammin/articleabstract/77/1-2/189/42585/The-crystal-structure-ofgarronite?redirectedFrom=fulltext
[6] L. B. McCusker, C. Baerlocher, R. Nawaz, Rietveld refinement of the crystal structure of the new zeolite mineral gobbinsite, Zeitschrift für Kristallografie, 171, 281-289 (1985).

https://rruff.info/doclib/zk/vol171/ZK171_281.pdf

[7] T. Bauer, W. Baur, Structural changes in the natural zeolite gismondine (GIS) induced by cation exchange with $\mathrm{Ag}, \mathrm{Cs}, \mathrm{Ba}, \mathrm{Li}, \mathrm{Na}, \mathrm{K}$ and $\mathrm{Rb}$, European Journal of Mineralogy, 10, 133-147 (1998). DOI: $10.1127 /$ ejm/10/1/0133.

[8] C. J. Adams, A. Araya, S. W. Carr, A. P. Chapple, P. Graham, A. R. Minihan, T. J. Osinga, Zeolite MAP: A new detergent builder, Zeolite Science 1994: Recent Progress and Discussions Studies in Surface Science and Catalysis, H. G. Karge and J. Weitkamp (Eds.). Elsevier Sci., 98, 206-207 (1995).

[9] S. Allen, S. Carr, A. Chapple, A. Dyer, B. Heywood, Ion exchange in the synthetic gismondine, zeolite MAP. Physical Chemistry, Chemical Physics, 4, 2409-2415 (2002). DOI: https://doi.org/10.1039/B111490P

[10] G. Vezzalini, A. Alberti, A. Sani, M. Triscari. The dehydration process in amicite, Microporous and Mesoporous Materials, 31, 253-262 (1999). DOI: 10.1016/S1387-1811(99)00076-1.

[11] G. M. Sheldrick, SHELX-97, University of Göttingen, Germany (1997). http://shelx.uni-ac.gwdg.de/SHELX/

[12] Agilent, CrysAlis PRO, version 1.171.36.20, Agilent Technologies Ltd, Yarnton, Oxfordshire, England (2012). https://www.agilent.com/cs/library/usermanuals/Public/ CrysAlis_Pro_User_Manual.pdf 